\title{
PERSEPSI DAN MOTIVASI WISATAWAN YANG BERKUNJUNG KE DAYA TARIK WISATA JEMBONG DI KABUPATEN BULELENG
}

\author{
Martina Minnie Anggela ${ }^{1}$, Ni Made Oka Karini ${ }^{2}$, Ni Made Sofia Wijaya ${ }^{3}$ \\ ${ }^{1}$ Email:minnieekecil@gmail.com \\ Program Studi S1 Industri Perjalanan Wisata, Fakultas Pariwisata, Universitas Udayana \\ 2Email: okakarini@gmail.com \\ Program Studi S1 Industri Perjalanan Wisata, Fakultas Pariwisata, Universitas Udayana \\ 32Email: mdsofiawij@gmail.com \\ Program Studi S1 Industri Perjalanan Wisata, Fakultas Pariwisata, Universitas Udayana
}

\begin{abstract}
The aim of this research is to determine the tourist perceptions and motivation that visit to Jembong tourist destination. This research was conducted at the Jembong tourist destination, Jembong District, Ambengan Village, Sukasada District, Buleleng Regency. The research method used is descriptive quantitative by distributed questionnaires to two hundred and twenty fivetourist that visiting Jembong tourist destination in Jembong district, Ambengan Village. A questionnaire consisted of twenty threestatements that refer to the theory of tourism development, which are tourist attraction, amenities, access and ancillary services and eighteen statements of tourist motivation that refer to the push and pull theory motivation. The potential tourist attraction in Jembong tourist destination are waterfall, trekking, and nature. The facilities are bathroom and change room, trash bin, restaurant, parking area, and gazebo. Local community who has an authority to make signboard and provided stairs and trail to facilitate tourists toward waterfall and trekking. Tourist information center made simultaneously with entrance ticket counter Jembong tourist destination. Promotion media at Jembong tourist destination are brochure, email and instagram. Maps of Jembong tourist destination is available in google maps therefore tourist easier toward Jembong tourist destination. The results of this research finding the higher of push motivation and pull motivation is related with beauty nature that suitable with the higher tourist perception to attraction are freshness air and beauty nature in Jembong tourist destination.
\end{abstract}

\begin{abstract}
Abstrak: Tujuan penelitian ini adalah untuk mengetahui persepsi dan motivasi wisatawan yang berkunjung ke daya tarik wisata Jembong, Dusun Jembong, Desa Ambengan, Kecamatan Sukasada, Kabupaten Buleleng. Metode penelitian yang digunakan dalam penelitian ini adalah deskriptif kuantitatif dengan cara menyebarkan kuisioner kepada 225 wisatawan yang berkunjung ke Daya Tarik Wisata Jembong di Dusun Jembong, Desa Ambengan. Kuisioner yang diberikan terdiri dari dua puluh tiga pernyataan mengenai persepsi wisatawan yang mengacu pada teori pengembangan pariwisata yaitu attraction, amenities, access dan ancilary services serta delapan belas pernyataan mengenai motivasi wisatawan yang mengacu pada teori push and pull motivation. Potensi yang ada di Daya Tarik Wisata Jembong adalah wisata air terjun, wisata trekking, dan wisata alam. Fasilitas yang disediakan adalah kamar mandi dan kamar ganti, tempat sampah, tempat makan dan minum, lahan parkir, dan gazebo. Pengelola membuat papan petunjuk arah untuk memudahkan wisatawan menuju daya tarik wisata Jembong. Pengelola juga menyediakan tangga dan jalan setapak untuk memudahkan wisatawan menuju air terjun dan trekking. Pusat informasi wisatawan dibuat bersamaan dengan loket masuk daya tarik wisata Jembong. Brosur sebagai media promosi cetak serta email dan instagram sebagai media promosi online. Peta lokasi daya atrik wisata Jembong telah tersedia di google maps sehingga wisatawan lebih mudah menuju daya tarik wisata Jembong. Hasil yang didapat dari penelitian ini adalah motivasi pendorong dan penarik yang mendapat nilai tertinggi adalah mengenai keindahan alam sesuai dengan persepsi wisatawan dengan nilai tertinggi adalah kesegaran udara dan keindahan alam di daya tarik wisata Jembong.
\end{abstract}

Keywords: Jembong district, motivation, perception, tourist, tourist destination. 


\section{PENDAHULUAN}

Kabupaten Buleleng merupakan salah satu kabupaten yang berada di Pulau Bali yang memiliki keindahan laut dan pantai serta budaya. Perekmbangan pariwisata di
Kabupaten Buleleng meningkat dibuktikan dengan jumlah kunjungan wisatawan yang meningkat di tahun 2016 sesuai dengan data dalam Tabel 1.

Tabel 1. Jumlah Kunjungan Wisatawan ke Kabupaten Buleleng

\begin{tabular}{cccc}
\hline Tahun & Nusantara & Mancanegara & Jumlah \\
\hline 2012 & 268.794 & 266.053 & 534.847 \\
\hline 2013 & 349.981 & 288.166 & 638.147 \\
\hline 2014 & 372.814 & 291.012 & 663.826 \\
\hline 2015 & 402.639 & 300.305 & 702.944 \\
\hline 2016 & 504.145 & 301.313 & 805.458 \\
\hline
\end{tabular}

Sumber: Dinas Pariwisata Kabupaten Buleleng, 2017

Seperti yang terlihat dalam grafik tersebut wisatawan yang berkunjung ke Kabupaten Buleleng meningkat sejak tahun 2012 hingga tahun 2016. Jumlah wisatawan ditahun 2016 sebanyak 504.145 wisatawan domestik dan 301.313 wisatawan asing. Jumlah ini meningkat dari tahun 2015 dengan presentase $14,6 \%$ Peningkatan ini dapat dinilai secara positif sebagai kemajuan pengembangan pariwisata di Kabupaten Buleleng. Wisata Air Terjun banyak ditemukan di Kabupaten Buleleng dikarenakan Kabupaten Buleleng yang berada pada dataran tinggi salah satunya berada di Dusun Jembong.
Dusun Jembong merupakan salah satu dusun yang berada di Desa Ambengan Kecamatan Sukasada Kabupaten Buleleng.

Dusun Jembong mempunyai satu Daya Tarik Wisata, yaitu Daya Tarik Wisata Jembong. Untuk mengelola daya tarik wisata yang ada di Dusun Jembong dibentuklah Kelompok Sadar Wisata Banten Koordinator Wilayah Jembong. Kelompok sadar wisata ini sudah terbentuk mulai dari tahun 2013. Dengan adanya kelompok sadar wisata, jumlah kunjungan wisatawan dapat terarsip dengan rapi. Berikut pertumbuhan jumlah kunjungan wisatawan di Dusun Jembong.

Grafik 1. Jumlah Kunjungan Wisatawan ke Daya Tarik Wisata Jembong

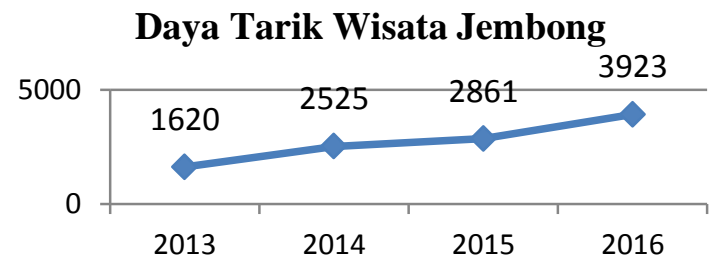

Sumber: Pokdarwis Banten Sari Koorwil Jembong, 2017

Dapat dilihat pada grafik diatas bahwa jumlah kunjungan wisatawan di Dusun Jembong mengalami peningkatan tiap tahunnya. Pada tahun 2016 meningkat sebanyak $1,37 \%$ dibandingkan tahun 2015 dengan jumlah wisatawan 3923 orang. Pada tahun 2015 kunjungan wisatawan ke Daya Tarik Wisata Jembong meningkat sebesar $1,13 \%$ dibandingkan tahun 2014 dengan jumlah wisatawan mencapai 2.861 orang. Sedangkan di tahun 2014 meningkat sebesar
1,56\% dibandingkan tahun 2013 dengan jumlah wisatawan 2.525 orang. Daya Tarik Wisata Jembong ini terdiri atas wisata air terjun, wisata trekking, kolam alami, kolam selfie dan pemandangan alam yang indah. Sebagai destinasi wisata yang baru berkembang, Daya Tarik Wisata Jembong berusaha untuk memberikan fasilitas yang dapat memuaskan wisatawan. Fasilitas yang telah disediakan di Daya Tarik Wisata Jembong diantaranya adalah kamar mandi dan 
kamar ganti, tempat parkir, tempat sampah, dan gazebo sebagai tempat peristirahatan wisatawan serta tempat makan dan minum yang menyediakan aneka makanan dan minuman.

Akses menuju daya tarik wisata Jembong berupa jalan pedesaan namun sudah menggunakan aspal. Terdapat pula papan petunjuk menuju daya tarik wisata Jembong dimulai dari jalan masuk awal dan juga terdapat baliho yang menunjukkan adanya daya tarik wisata Jembong. Pihak pengelola sudah membuat tangga dan jalan setapak menuju air terjun Jembong sehingga memudahkan wisatawan. Pelayanan penunjang yang ada di daya tarik wisata Jembong diantaranya adalah adanya loket masuk yang dikelola oleh Kelompok Sadar Wisata Banten Sari Koordinator Wilayah Jembong yang sekaligus menjadi pusat informasi bagi wisatawan. Pengelola juga membuat akun instagram dan email agar wisatawan mudah mendapat informasi melalui media sosial. Peta lokasi daya tarik wisata Jembong juga dapat diakses secara mudah oleh wisatawan di google maps sehingga wisatawan dapat menuju daya tarik wisata Jembong dengan mudah.

Daya tarik wisata Jembong belum termasuk dalam SK Bupati Buleleng tentang daya tarik wisata namun wisatawan yang mengunjungi daya tarik wisata Jembong meningkat sejak tahun 2013. Meningkatnya jumlah kunjungan wisatawan yang berkunjung ke Daya Tarik Wisata Jembong dipengaruhi oleh persepsi dan motivasi wisatawan. Semakin positif persepsi wisatawan akan fasilitas yang disediakan maka semakin banyak wisatawan yang mengunjungi Daya Tarik Wisata Jembong. Dengan diketahuinya motivasi wisatawan, pihak pengelola dapat meningkatkan hal yang menjadi alasan wisatawan mengunjungi Daya Tarik Wisata Jembong. Hal inilah yang menjadi landasan peneliti untuk meneliti "Persepsi dan Motivasi Wisatawan yang Berkunjung ke Daya Tarik Wisata Jembong, di Dusun Jembong Desa Ambengan Kecamatan Sukasada Kabupaten Buleleng." Adapun tujuan dalam penelitian ini adalah:

1. Mengetahui motivasi wisatawan yang mengunjungi Daya Tarik Wisata Jembong di Dusun Jembong, Desa Ambengan, Kecamatan Sukasada, Kabupaten Buleleng.
2. Mengetahui persepsi wisatawan terhadap komponen 4A di Daya Tarik Wisata Jembong di Dusun Jembong, Desa Ambengan, Kecamatan Sukasada, Kabupaten Buleleng.

\section{TINJAUAN PUSTAKA Wisatawan}

Wisatawan merupakan salah satu dari stakeholder pariwisata yang banyak para ahli telah mengungkapkan pendapatnya mengenai arti dari wisatawan itu sendiri. Secara umum wisatawan adalah seseorang atau sekelompok orang yang meninggalkan daerah asalnya untuk mengunjungi suatu daerah yang ingin dikunjunginya dengan lama waktu lebih dari 24 jam dengan tujuan untuk bersenang-senang. Menurut Undang Undang No 10 Tahun 2009 tentang Pariwisata, wisatawan adalah orang yang melakukan wisata. Menurut Instruksi Presiden No. 9 Tahun 1969 "wisatawan (tourist) adalah setiap orang yang berpergian dari tempat tinggalnya untuk berkunjung ke tempat lain dengan menikmati perjalanannya dan kunjungannya itu." Wisatawan dalam penelitian ini adalah wisatawan baik itu mancanegara maupun lokal yang mengunjungi Daya Tarik Wisata Jembong baik yang melakukan aktivitas trekking maupun hanya sekedar berfoto di air terjun Jembong.

\section{Motivasi}

Motivasi dapat dikatakan sebagai alasan wisatawan untuk berwisata mengunjungi daerah-daerah baru yang belum pernah dikunjunginya. Menurut Cohen, (1984) dalam Pitana dan Gayatri, (2005) motivasi dipandang sebagai proses singkat untuk melihat perilaku perjalanan wisata, ke arah yang lebih menekankan bagaimana motovasi mempengaruhi kebutuhan psikologis dan rencana jangka panjang seseorang, dengan melihat bahwa motif intrinsik (seperti self actualisation) sebagai komponen yang sangat penting.

Konsep Moslow tentang hierarki kebutuhan yang dimulai dari kebutuhan fisiologis, kebutuhan keamanan, kebutuhan sosial, kebutuhan prestise dan kebutuhan aktualisasi diri, telah dijadikan dasar untuk meneliti motivasi wisatawan oleh Pierce (1988) dan Pearce dan Caltabiano (1983), yang antara lain menemukan bahwa motivasi perjalanan sworang wisatawan bisa berubah- 
ubah dari waktu ke waktu dalam suatu proses yang dinamis. Pierce (1988) dalam Pitana dan Gayatri, (2005) menemukan bahwa self actualization dan social needs menempati urutan tertinggi.

Selain motivasi yang dikonsepkan oleh Moslow, terdapat juga sebuah teori motivasi yang disebut dengan push and pull motivation. Teori ini terdapat di travel motivation. Push and pull motivation ini menjelaskan mengenai motivasi wisatawan dilihat dari faktor-faktor penarik dan faktor-faktor pendorongnya. Konsep motivasi ini dilatar belakangi oleh faktor-faktor yang ada di sekitar wisatawan. Faktor pendorong terbentuk dari faktor-faktor intangible yang berasal dari dalam diri wisatawan itu sendiri. Sedangkan faktor penarik terbentuk oleh faktor-faktor tangible yang ada di obyek wisata seperti keunikan obyek wisata, atraksi wisata dan potensi wisata lainnya. Crompton (1979) dalam Ahmad Puat Mat Som (2010) pertama kali mengambarkan tujuh faktor sosio-psikologi, atau motivasi pendorong (escape, self-exploratory, relaxation, prestige, regression, kinshipenhancement, and social interaction) dan dua faktor budaya, atau motivasi penarik (novelty and education).

Selain Crompton, Dann (1977) dalam Pitana (2005) memandang bahwa faktor pendorong utama seseorang untuk melakukan perjalanan wisata (khususnya dari negara Barat ke Dunia Ketiga) adalah untuk melepaskan diri dari tekanan psikis dalam kehidupan sehari-hari di negara industri. secara sederhana menjelaskan faktor pendorong sebagai motivasi wisatawan untuk pergi jauh dari rumah dan faktor penarik sebagai motivasi yang membuat wisatawan mengunjungi destinasi wisata. Gray (1970) dalam Crompton (1977) mendefinisikan motivasi pendorong dan penarik sebagai 'sunlust' dan 'wanderlust'. Sunlust mendeskripsikan bahwa 'liburan yang termotivasi oleh keinginan untuk mengalami fasilitas yang berbeda atau lebih baik untuk tujuan tertentu daripada yang tersedia di lingkungan di mana biasanya hidup. Wanderlust dideskripsikan sebagai "sifat dasar dalam sifat manusia yang menyebabkan beberapa orang ingin meninggalkan hal-hal yang biasa bagi mereka dan pergi serta melihat budaya yang ada dan tempat yang berbeda secara langsung. Motivasi wisatawan yang digunakan dalam penelitian ini adalah konsep
Crompton yang menjelaskan mengenai motivasi pendorong dan penarik.

\section{Persepsi}

Persepsi merupakan pendapat yang berbeda-beda yang dimiliki oleh setiap orang terhadap objek yang sama. Arti dari persepsi sendiri juga sudah banyak diungkapkan oleh para ahli diantaranya adalah persepsi merupakan proses internal yang diakui individu dalam menyeleksi, dan mengatur stimuli yang datang dari luar. Stimuli itu ditangkap oleh indera, secara spontan pikiran dan perasaan kita akan memberi makna atas stimulti tersebut. Menurut Suranto Aw (2010) secara sederhana persepsi dapat dikatakan sebagai proses individu dalam memahami kontak/hubungan dengan dunia sekelilingnya. Selain itu, menurut Sarwono, (2009) persepsi merupakan pengalaman untuk membedabedakan, mengelompokkan, memfokuskan dan sebagainya itu selanjutnya di interorientasi.

Menurut Murianto (2014) persepsi merupakan cara pandang, tindakan dan gambaran yang diberikan seseorang terhadap sesuatu yang berada di sekitar lingkungannya baik persepsi yang diberikan positif atau negatif. Persepsi yang dimaksud dalam penelitian ini adalah persepsi wisatawan terhadap komponen 4A Daya Tarik Wisata Jembong.

\section{Daya Tarik Wisata}

Menurut Undang-Undang No 10 tahun 2009 tentang Kepariwisataan menyatakan bahwa daerah tujuan pariwisata yang selanjutnya disebut Destinasi Pariwisata adalah kawasan geografis yang berada dalam satu atau lebih wilayah administratif yang di dalamnya terdapat daya tarik wisata, fasilitas umum, fasilitas pariwisata, aksesibilitas, serta masyarakat yang saling terkait dan melengkapi terwujudnya kepariwisataan.Daya Tarik Wisata menurut Undang-Undang No 10 Tahun 2009 tentang Kepariwisataan adalah segala sesuatu yang memiliki keunikan, keindahan, dan nilai yang berupa keanekaragaman kekayaan alam, budaya, dan hasil buatan manusia yang menjadi sasaran atau tujuan kunjungan wisatawan. Menurut Marpaung (2002) objek dan daya tarik wisata adalah suatu bentukan 
dan/atau aktivitas dan fasilitas yang berhubungan, yang dapat menarik minat wisatawan atau pengunjung untuk datang ke suatu daerah/tempat tertentu. Daya tarik wisata menurut Direktorat Jendral Pemerintahan di bagi menjadi tiga macam, yaitu:

1. Daya Tarik Wisata Alam

Daya Tarik Wisata Alam adalah sumber daya alam yang berpotensi serta memiliki daya tarik bagi pengunjung baik dalam keadaan alami maupun setelah ada usaha budi daya. Potensi wisata alam dapat dibagi menjadi 4 kawasan yaitu :

a. Flora fauna

b. Keunikan dan kekhasan ekosistem, misalnya eksistem pantai dan ekosistem hutan bakau

c. Gejala alam,misalnya kawah, sumber air panas, air terjun dan danau

d. Budidaya sumber daya alam, misalnya sawah, perkebunan, peternakan, usaha perikanan

2. Daya Tarik Wisata Sosial Budaya

Daya Tarik Wisata Sosial Budaya dapat dimanfaatkan dan dikembangkan sebagai objek dan daya tarik wisata meliputi museum, peninggalan sejarah, upacara adat, seni pertunjukan dan kerajinan. Marpaung (2002) mengelompokkan daya tarik wisata sosial budaya menjadi beberapa bagian, diantaranya adalah:

a. Peninggalan Sejarah Kepurbakalaan dan Monumen

b. Museum dan Fasilitas Budaya Lainnya

c. Pola Kehidupan

d. Desa Wisata

e. Wisata Keagamaan, Etnis dan Nostalgia

2. Daya Tarik Wisata Minat Khusus

Daya Tarik Wisata Minat Khusus merupakan jenis wisata yang baru dikembangkan di Indonesia. Wisata ini lebih diutamakan pada wisatawan yang mempunyai motivasi khusus. Dengan demikian, biasanya para wisatawan harus memiliki keahlian. Contohnya: berburu mendaki gunung, arung jeram, tujuan pengobatan, agrowisata, dll.

Cooper, et al. (1993) dalam Suwena (2010) menjelaskan bahwa Daerah Tujuan
Wisata harus didukung empat komponen utama yang dikenal dengan istilah " $4 \mathrm{~A}$ " yaitu:

1. Atraction atau atraksi adalah objek atau daya tarik wisata yang dimiliki oleh suatu lokasi. Atraksi yang menarik kedatangan wisatawan ada tiga yaitu potensi alam, wisata budaya dan wisata buatan.

2. Amenities atau fasilitas merupakan fasilitasfasilitas yang menunjang kegiatan pariwisata di daerah tujuan wisata seperti akomodasi atau usaha penginapan, restoran atau usaha makanan dan minuman serta fasilitas umum seperti toilet, toko oleh-oleh dan lainnya.

3. Accessibility atau aksesibilitas merupakan kemudahan untuk bergerak bagi wisatawan, mulai dari kemudahan jalan menuju objek wisata hingga kemudahan mencari objek wisata tersebut.

4. Ancillary service atau pelayanan tambahan merupakan pelayanan yang menunjang kegiatan pariwisata seperti adanya kelompok sadar wisata atau lembaga swasta untuk mengelola pengembangan wisata di suatu daerah tujuan wisata, adanya TIC (Tourist Information Center) yang memberikan informasi kepada wisatawan baik berupa brosur, buku, peta dan lain sebagainya serta adanya pemandu wisata yang kompeten di bidangnya dan menguasai objek wisata dimana dia bekerja.

Daya tarik wisata yang dimaksud dalam penelitian ini adalah Daya Tarik Wisata Jembong yang terdiri dari air terjun dan trekking yang termasukdalam daya tarik wisata alam yang berada di Dusun Jembong, Kecamatan Sukasada, Kabupaten Buleleng.

\section{METODE}

Lokasi yang menjadi tempat penelitian ini adalah Daya Tarik Wisata Jembong yang berada di Desa Jembong, Dusun Ambengan, Kecamatan Sukasada, Kabupaten Buleleng.

Persepsi yang digunakan dalam penelitian ini adalah persepsi wisatawan yang diukur dari konsep 4A yang dipaparkan oleh Cooper, et al. (1993) dalam Suwena (2010). Indikator yang diajukan kepada wisatawan diantaranya yaitu: 
Tabel 2. Definisi Operasional Variabel Persepsi

\begin{tabular}{|c|c|}
\hline Variabel & Indikator \\
\hline Atraction & $\begin{array}{ll}\text { 1. } & \text { Keindahan alam di Daya Tarik Wisata Jembong } \\
\text { 2. } & \text { Kesegaran Udara di Daya Tarik Wisata Jembong } \\
\text { 3. } & \text { Kebersihan di Daya Tarik Wisata Jembong } \\
\text { 4. } & \text { Keunikan air terjun di Daya Tarik Wisata Jembong } \\
\text { 5. Kesegaran air kolam alami di Daya Tarik Wisata Jembong } \\
\text { 6. } & \text { Keunikan kolam selfie di daya tarik wisata Jembong } \\
\text { 7. } & \text { Jalur Trekking yang menarik }\end{array}$ \\
\hline Amenities & $\begin{array}{l}\text { 1. Ketersediaan kamar mandi dan kamar ganti di Daya Tarik Wisata } \\
\text { Jembong } \\
\text { 2. Tersedianya fasilitas lahan parkir di Daya Tarik Wisata Jembong } \\
\text { 3. Tersedianya fasilitas tempat sampah di sekitar Daya Tarik Wisata } \\
\text { Jembong } \\
\text { 4. Tersedianya fasilitas gazebo atau bale bengong sebagai tempat } \\
\text { istirahat di Daya Tarik Wisata Jembong } \\
\text { 5. Tersedianya tempat makan dan minum di Daya Tarik Wisata } \\
\text { Jembong } \\
\text { 6. Tersedianya toko cinderamata khas di Daya Tarik Wisata Jembong }\end{array}$ \\
\hline Acces & $\begin{array}{l}\text { 1. Mudahnya akses menuju Daya Tarik Wisata Jembong } \\
\text { 2. Adanya papan petunjuk menuju Daya Tarik Wisata Jembong untuk } \\
\text { memudahkan wisatawan menuju daya atrik wisata Jembong } \\
\text { 3. Mudahnya jalur trekking atau jalur menuju Air Terjun Jembong } \\
\text { 4. Adanya tangga menuju Air Terjun untuk memudahkan wisatawan } \\
\text { 5. Adanya jalan setapak menuju Air Terjun untuk memudahkan } \\
\text { wisatawan }\end{array}$ \\
\hline Ancilary Service & $\begin{array}{l}\text { 1. Tersedianya Brosur Wisata sebagai Media Promosi di Daya Tarik } \\
\text { Wisata Jembong } \\
\text { 2. Adanya Pusat Informasi Wisatawan di daya tarik Wisata Jembong } \\
\text { 3. Adanya peta yang menunjukkan lokasi Daya tarik Wisata Jembong } \\
\text { 4. Tersedianya email dan instagram sebagai media promosi dan } \\
\text { informasi di daya tarik wisata Jembong }\end{array}$ \\
\hline
\end{tabular}

Sumber: Penulis, 2016.

\section{Motivasi}

Motivasi wisatawan yang digunakan dalam penelitian ini adalah push and pull motivation yang dikenalkan oleh Crompton (1979) dengan indikator sebagai berikut:

Tabel 3. Definisi Operasional Variabel Motivasi

\begin{tabular}{cll}
\hline Variabel & & \multicolumn{1}{c}{ Indikator } \\
\hline Push Factor & 1. & Untuk mengunjungi daya tarik wisata yang belum pernah dikunjungi \\
& sebelumnya & \\
& 2. Untuk mewujudkan mimpi mengunjungi daya tarik wisata \\
& 3. Untuk mengunjungi daya tarik wisata yang pernah dikunjungi oleh teman \\
& 4. Untuk mendapatkan pengalaman baru di tempat yang baru \\
& 5. Untuk merelaksasikan diri \\
& 6. Untuk melepaskan diri dari rutinitas sehari-hari \\
& 7. Untuk menikmati alam pedesaan dan suasana air terjun \\
& 8. Untuk menikmati waktu dengan teman seperjalanan \\
\hline Pull Factor & 9. Untuk melakukan trekking di daya tarik wisata baru \\
\hline
\end{tabular}



2. Pemandangan alam yang indah
3. Air yang jernih
4. Air terjun yang unik
5. Kolam alami dibawah air terjun
6. Spot foto unik di kolam selfie
7. Jalur Trekking yang mudah untuk dilalui
8. Pemandangan sawah terasering dan kebun cengkeh selama trekking
9. Spot foto yang eksotis di pusat trekking

Sumber: Penulis, 2016.

Penelitian ini menggunakan data kuantitatif yang berbentuk informasi berupa gambaran umum, dan data kualitatif yang berbentuk angka berupa hasil kuesioner, jumlah responden, jumlah kunjungan wisata di daya tarik wisata Jembong. Sumber data dalam penelitian ini adalah data primer dan data sekunder. Data primer yang dimaksud adalah data dari hasil kuesioner, data sekunder yang dimaksud adalah data profil desa, dan data jumlah kunjungan wisatawan.

Teknik penentuan sampel yang peneliti gunakan adalah accidental sampling dengan responden yang diambil merupakan wisatawan yang berkunjung ke daya tarik wisata Jembong. Ukuran sampel yang digunakan dalam penelitian ini menggunakan hasil perhitungan yang telah dilakukan oleh Isaac dan Michael dalam Sugiyono (2014) yang telah dibuatkan tabel dengan jumlah populasi dan 3 macam taraf kesalahan sehingga didapatkan hasil jumlah sampel yang harus dicari. Dalam penelitian ini populasi adalah jumlah kunjungan wisatawan rata-rata perbulan yang diambil pada tahun 2016 $(3923 / 12=326$ kemudian dibulatkan menjadi 340) dengan taraf kesalahan $1 \%$ sehingga didapatkan hasil 225. Hasil inilah yang menjadi jumlah sampel yang dicari oleh peneliti.

Analisis data deskriptif kuantitatif merupakan teknik analisis data yang digunakan oleh peneliti. Untuk menganalisis motivasi dan persepsi wisatawan menggunakan skala likert sesuai dengan yang diungkapkan oleh Sugiyono (2015). Variabel penelitian dijabarkan menjadi indikator berupa pernyataan yang kemudian akan menghasilkan skor sesuai dengan gradasi skala likert yang digunakan. Dalam penelitian ini menggunakan pemberian skor 1-5 dengan gradasi dari sangat setuju sampai sangat tidak setuju. Penyajian data dilakukan setelah data penelitian selesai dianalisis. Prinsip dasar penyajian data adalah komunikatif dan lengkap sesuai dengan yang dikemukakan oleh Sugiyono (2007). Penyajian data dalam penelitian ini adalah penyajian data dalam bentuk tabel. Tabel yang disajikan dalam penelitian ini adalah tabel yang berisi data yang telah diolah menjadi data prosentase dan juga tabel yang berisi sikap wisatawan pada setiap indikator variabel. Penjabaran secara deskriptif yang dilakukan peneliti untuk menjelaskan data dalam tabel yang disajikan.

\section{HASIL DAN PEMBAHASAN}

Daya tarik wisata Jembong memiliki beberapa atraksi wisata diantaranya adalah wisata alam, wisata trekking dan wisata air terjun. Wisata alam menawarkan kepada wisatawan untuk menikmati keindahan pemandangan yang ada di daya tarik wisata Jembong. Wisata trekking menawarkan kepada wisatawan untuk menjelajahi alam yang masih alamidi dusun Jembong. Wisata air terjun menawarkan kepada wisatawan keindahan air terjun yang berundak beserta kesegaran air di kolam alami yang terdapat di bawah air terjun.

Wisatawan yang datang berkunjung ke daya tarik wisata Jembong berdasarkan jenis kelamin dapat dikatakan seimbang. Hal ini dilihat dari hasil penelitian yang menyatakan bahwa 49,8\% wisatawan berjenis kelamin perempuan dan $50,2 \%$ berjenis kelamin lakilaki. Wisatawan yang berkunjung ke daya tarik wisata Jembong bila dilihat berdasarkan usia yang menempati urutan teratas adalah wisatawan dengan usia 15-24 tahun dengan $62,7 \%$. Sedangkan untuk wisatawan usia $25-$ 44 tahun sebanyak 30,2\%, usia 45-64 tahun sebanyak 3,6\%. Usia 0-14 tahun sebanyak $2,2 \%$ dan wisatawan yang sedikit terletak pada usia $>65$ tahun sebanyak $0,9 \%$. 
Tabel 4. Jenis Kelamin Wisatawan

\begin{tabular}{ccc}
\hline Jenis Kelamin & Frekuensi (orang) & Prosentase (\%) \\
\hline Laki-laki & 113 & 50,2 \\
\hline Perempuan & 112 & 49,8
\end{tabular}

Sumber: Hasil Penelitian, 2017.

Tabel 5. Usia Wisatawan

\begin{tabular}{ccc}
\hline Usia (tahun) & Frekuensi (orang) & Prosentase (\%) \\
\hline $0-14$ & 5 & $2,2 \%$ \\
\hline $15-24$ & 141 & $62,7 \%$ \\
\hline $25-44$ & 68 & $30,2 \%$ \\
\hline $45-64$ & 8 & $3,6 \%$ \\
\hline$>65$ & 2 & $0,9 \%$
\end{tabular}

Sumber: Hasil Penelitian, 2017.

Wisatawan dilihat berdasarkan tingkat pendidikan didapat hasil bahwa wisatawan yang dominan berkunjung ke daya tarik wisata jembong adalah wisatawan dengan tingkat pendidikan Sarjana sebanyak 44,9\%. Wisatawan dengan tingkat pendidikan SD sebanyak $1,3 \%$; wisatawan dengan tingkat pendidikan SMP sebanyak 1,3\%; wisatawan dengan tingkat pendidikan SMU sebanyak $35,6 \%$; wisatawan dengan tingkat pendidikan
Diploma 12,4\%; wisatawan dengan tingkat pendidikan Pasca Sarjana sebanyak 1,8\%; dan yang terakhir wisatawan dengan tingkat pendidikan Magister sebanyak 1,8\%. Hasil penelitian wisatawan berdasarkan tingkat pendidikan ini membuktikan bahwa wisatawan dengan tingkat pendidikan sarjana lebih tertarik untuk mengunjungi daya tarik wisata baru yang lebih menawarkan keindahan alam.

Tabel 6. Tingkat Pendidikan Wisatawan

\begin{tabular}{lcc}
\hline Tingkat Pendidikan & Frekuensi (orang) & Prosentase (\%) \\
\hline SD/sederajat & 3 & $1,3 \%$ \\
\hline SMP/sederajat & 3 & $1,3 \%$ \\
\hline SMU/sederajat & 80 & $35,6 \%$ \\
\hline Diploma & 28 & $12,4 \%$ \\
\hline Sarjana & 101 & $44,9 \%$ \\
\hline Pasca Sarjana & 4 & $1,8 \%$ \\
\hline Magister & 4 & $1,8 \%$
\end{tabular}

Sumber: Hasil Penelitian, 2017.

Wisatawan dilihat berdasarkan benua asal wisatawan yang dominan berkunjung ke daya tarik wisata Jembong adalah Asia sebanyak $87,6 \%$. Wisatawan yang berasal dari Amerika sebanyak 3,6\%; wisatawan yang berasal dari Eropa sebanyak 6,2\%; wisatawan yang berasal dari Australia sebanyak 2,7\%. Hal ini berkaitan dengan daerah asla wisatawan yang berkunjung ke daya tarik wisata Jembong. Wisatawan yang berasal dari luar negeri sebanyak $12,4 \%$ yang merupakan gabungan antara Amerika, Eropa dan Australia. Sedangkan wisatawan yang berasal dari Asia dibagi menjadi 3 daerah yaitu wisatawan yang berasal dari dalam kabupaten Buleleng sebanyak 54,2\%; wisatawan yang berasal dari luar kabupaten Buleleng namun masih satu Provinsi sebanyak 19,6\%; wisatawan yang berasal dari luar kabupaten Buleleng dan lain Provinsi sebanyak 13,8\%. 
Tabel 7. Benua Asal Wisatawan

\begin{tabular}{lcc}
\hline \multicolumn{1}{c}{ Benua } & Frekuensi (orang) & Prosentase $(\%)$ \\
\hline Amerika & 8 & $3,6 \%$ \\
\hline Eropa & 14 & $6,2 \%$ \\
\hline Australia & 6 & $2,7 \%$ \\
\hline Asia & 197 & $87,6 \%$ \\
\hline
\end{tabular}

Sumber: Hasil Penelitian, 2017.

Tabel 8. Daerah Asal Wisatawan

\begin{tabular}{lcc}
\hline \multicolumn{1}{c}{ Daerah Asal } & Frekuensi (orang) & Prosentase (\%) \\
\hline Luar Negeri & 28 & $12,4 \%$ \\
\hline Dalam Kabupaten Buleleng & 122 & $54,2 \%$ \\
\hline Luar Kabupaten Buleleng (Satu Provinsi) & 44 & $19,6 \%$ \\
\hline Luar Kabupaten Buleleng (Lain Provinsi) & 31 & $13,8 \%$ \\
\hline
\end{tabular}

Sumber: Hasil Penelitian, 2017.

Wisatawan berdasarkan status pernikahan, wisatawan yang berkunjung ke daya tarik wisata Jembong dominan belum menikah sebanyak $82,7 \%$. Wisatawan yang menikah sebanyak $15,1 \%$ dan wisatawan yang cerai sebanyak $2,2 \%$. Hal ini menunjukkan bahwa status pernikahan juga merupakan faktor penentu untuk melakukan perjalanan. Wisatawan yang belum menikah lebih banyak melakukan perjalanan mengunjungi daya tarik wisata yang belum pernah dikunjungi.

Tabel 9. Status Pernikahan

\begin{tabular}{lcc}
\hline $\begin{array}{c}\text { Status } \\
\text { Pernikahan }\end{array}$ & $\begin{array}{c}\text { Frekuensi } \\
\text { (orang) }\end{array}$ & Prosentase (\%) \\
\hline Belum Menikah & 186 & $82,7 \%$ \\
\hline Menikah & 34 & $15,1 \%$ \\
\hline Cerai & 5 & $2,2 \%$ \\
\hline
\end{tabular}

Sumber: Hasil Penelitian, 2017.

Tabel 10. Pekerjaan Wisatawan

\begin{tabular}{lcc}
\hline \multicolumn{1}{c}{ Pekerjaan } & $\begin{array}{c}\text { Frekuensi } \\
\text { (orang) }\end{array}$ & Prosentase (\%) \\
\hline PNS & 13 & $5,8 \%$ \\
\hline Pegawai Swasta & 46 & $20,4 \%$ \\
\hline Polisi/Tentara & 2 & $0,9 \%$ \\
\hline Wiraswasta & 25 & $11,1 \%$ \\
\hline Pengusaha & 6 & $2,7 \%$ \\
\hline Profesional & 5 & $2,2 \%$ \\
\hline Pensiunan & 2 & $0,9 \%$ \\
\hline Ibu Rumah Tangga & 4 & $1,8 \%$ \\
\hline Pelajar/Mahasiswa & 109 & $48,4 \%$ \\
\hline Lainnya & 10 & $4,4 \%$ \\
\hline
\end{tabular}

Sumber: Hasil Penelitian, 2017.

Berdasarkan pekerjaan wisatawan yang berkunjung ke daya tarik wisata Jembong dominan merupakan pelajar/mahasiswa sebanyak 48,4\%. Wisatawan yang bekerja sebagai PNS sebanyak 5,8\%; Pegawai swasta sebanyak 20,4\%; polisi/tentara hanya $0,9 \%$; 
wiraswasta sebanyak $11,1 \%$; pengusaha $2,7 \%$; profesional $2,2 \%$; pensiunan hanya $0,9 \%$; ibu rumah tangga sebanyak $1,8 \%$; dan lainnya sebanyak 4,4\%. Hal ini menunjukkan bahwa pelajar/mahasiswa merupakan wisatawan yang paling banyak berkunjung ke daya tarik wisata yang baru. Pekerjaan wisatawan ini berkaiatan dengan tingkat pendidikan wisatawan yang dominan sarjana dan juga usia wisatawan dominan 15-24 tahun.

Tabel 11. Lama Kunjungan

\begin{tabular}{lcc}
\hline Lama Kunjungan & Frekuensi (orang) & $\begin{array}{c}\text { Prosentase } \\
(\%)\end{array}$ \\
\hline 4-12 jam & 208 & $92,4 \%$ \\
\hline 13-24 jam & 2 & $0,9 \%$ \\
\hline$>24$ jam & 7 & $3,1 \%$ \\
\hline
\end{tabular}

Sumber: Hasil Penelitian, 2017.

Berdasarkan lama kunjungan wisatawan sesuai dengan tabel 8 diatas wisatawan yang paling banyak berkunjung adalah wisatawan dengan lama kunjungan 4-12 jam sebanyak $92,4 \%$. Sedangkan wisatawan dengan lama kunjungan 13-24 jam sebanyak 0,9\%; lama kunjungan $>24$ jam sebanyak 3,1\%. Sedangkan untuk waktu kunjungan wisatawan ke daya tarik wisata Jembong yang paling dominan wisatawan berkunjung pada akhir pekan sebanyak $34,7 \%$. Wisatawan yang berkunjung pada hari biasa sebanyak $34,2 \%$; wisatawan yang berkunjung pada hari libur sebanyak 21,8\%; dan wisatawan yang berkunjung pada libur sekolah sebanyak 7,6\%.

Tabel 12. Waktu Kunjungan

\begin{tabular}{lcc}
\hline Waktu Kunjungan & Frekuensi (orang) & Prosentase (\%) \\
\hline Hari Biasa & 77 & $34,2 \%$ \\
\hline Akhir Pekan & 78 & $34,7 \%$ \\
\hline Hari Libur & 49 & $21,8 \%$ \\
\hline Libur Sekolah & 17 & $7,6 \%$ \\
\hline
\end{tabular}

Sumber: Hasil Penelitian, 2017.

\section{Persepsi Wisatawan yang Berkunjung ke} Daya tarik Wisata Jembong

Terdapat tujuh indikator yang dinyatakan oleh peneliti yang kemudian ditanyakan persepsinya kepada wisatawan. Rata-rata wisatawan memberikan persepsi setuju terhadap indikator atraksi yang ada di daya tarik wisata Jembong. Untuk indikator yang mendapat skor tertinggi dari wisatawan adalah kesegaran udara di daya tarik wisata jembong dengan skor 998 dan mendapat klasifikasi sikap sangat setuju. Hal ini dikarenakan daya tarik wisata Jembong tergolong dalam wisata alam yang mempertahankan keindahan alam disekitarnya. Sedangkan indikator yang mendapat skor paling rendah adalah jalur trekking yang menarik dengan jumlah skor 842 dan mendapatkan klasifikasi sikap setuju. Tidak semua wisatawan yang mengunjungi daya tarik wisata Jembng mencoba aktivitas trekking yang ditawarkan sehingga tidak banyak wisatawan memberikan penilaian untuk indikator ini.

Tabel 13. Persepsi Wisatawan terhadap Attraction

\begin{tabular}{clcc}
\hline No & \multicolumn{1}{c}{ Indikator Attraction } & Skor & Klasifikasi Sikap \\
\hline 1 & Keindahan alam di Daya Tarik Wisata Jembong & 997 & Sangat Setuju \\
\hline 2 & Kesegaran Udara di Daya Tarik Wisata Jembong & 998 & Sangat Setuju \\
\hline 3 & Kebersihan di Daya Tarik Wisata Jembong & 884 & Setuju \\
\hline 4 & Keunikan air terjun di Daya Tarik Wisata Jembong & 941 & Setuju \\
\hline 5 & Kesegaran air kolam alami di Daya Tarik Wisata & 982 & Sangat Setuju \\
\hline
\end{tabular}




\begin{tabular}{clcc}
\hline Jembong & & \\
\hline 6 & Keunikan kolam selfie di daya tarik wisata Jembong & 924 & Setuju \\
\hline 7 & Jalur Trekking yang menarik & 842 & Setuju \\
\hline \multicolumn{2}{c}{ Rata-rata } & 938,3 & Setuju \\
\hline
\end{tabular}

Sumber: Hasil Penelitian, 2017.

Indikator keindahan alam di daya tarik wisata Jembong mendapat jumlah skor 997 dengan klasifikasi sikap sangat setuju. Indikator ini masih berhubungan dengan konsep daya tarik wisata Jembong. Inikator kebersihan daya tarik wisata Jembong mendapat jumlah skor 884 dengan klasifikasi sikap setuju. Hal ini dikarenakan sampah daun-daun kering yang gugur ke dalam kolam alami tidak langsung dibersihkan oleh kelompok sadar wisata. Namun untuk sampah hasil pembuangan dari manusia seperti plastik makanan maupun botol minum, wisatawan langsung membuangnya di tempat sampah yang telah tersedia di beberapa lokasi di daya tarik wisata Jembong. Indikator keunikan air terjun di daya tarik wisata Jembong mendapat jumlah skor 941 dengan klasifikasi sikap setuju. Indikator kesegaran air kolam alami di daya tarik wisata jembong mendapat persepsi sangat setuju dengan jumlah skor 982 . Indikator keunikan kolam selfie di daya tarik wisata Jembong mendapat persepsi setuju dari wisatawan dengan total skor 924 .

Tabel 14. Persepsi Wisatawan terhadap Amenities

\begin{tabular}{clcc}
\hline No & \multicolumn{1}{c}{ Indikator Amenities } & Skor & $\begin{array}{c}\text { Klasifikasi } \\
\text { Sikap }\end{array}$ \\
\hline 1 & $\begin{array}{l}\text { Ketersediaan kamar mandi dan kamar ganti di Daya Tarik } \\
\text { Wisata Jembong }\end{array}$ & 843 & Setuju \\
\hline 2 & $\begin{array}{l}\text { Tersedianya fasilitas lahan parkir di Daya Tarik Wisata } \\
\text { Jembong }\end{array}$ & 866 & Setuju \\
\hline 3 & $\begin{array}{l}\text { Tersedianya fasilitas tempat sampah di sekitar Daya Tarik } \\
\text { Wisata Jembong }\end{array}$ & 867 & Setuju \\
\hline 4 & $\begin{array}{l}\text { Tersedianya fasilitas gazebo atau bale bengong sebagai } \\
\text { tempat istirahat di Daya Tarik Wisata Jembong }\end{array}$ & 908 & Setuju \\
\hline 5 & $\begin{array}{l}\text { Tersedianya tempat makan dan minum di Daya Tarik Wisata } \\
\text { Jembong }\end{array}$ & 820 & Setuju \\
\hline 6 & $\begin{array}{l}\text { Tersedianya toko cinderamata khas di Daya Tarik Wisata } \\
\text { Jembong }\end{array}$ & 733 & Ragu-Ragu \\
\hline \multicolumn{1}{c}{ Rata-rata } & 839,5 & Setuju \\
\hline Sum
\end{tabular}

Sumber: Hasil Penelitian, 2017.

Variabel amenities terdapat 6 indikator yang dinyatakan oleh peneliti yang kemudian dijawab oleh wisatawan. Rata-rata wisatawan memberikan persepsi setuju dengan total skor rata-rata 839,5. Indikator yang mendapat skor paling tinggi dari wisatawan adalah terdapatnyagazeboatau bale bengong di daya tarik wisata Jembong. Indikator ini mendapat persepsi setuju dari wisatawan dengan total skor 908. Indikator yang mendapat total skor paling sedikit adalah tersedianya toko cinderamata khas di daya tarik wisata Jembong. Indikator ini mendapat persepsi ragu-ragu dengan total skor 733 . Hal ini diakrenakan tidak adanya toko cinderamata khas di daya tarik wisata Jembong dan juga beberapa wisatawan berpendapat bahwa sudah terlalu banyak toko cinderamata di setiap daya tarik wisata.

Indikator ketersediaan kamar mandi dan kamar ganti di daya tarik wisata Jembong mendapat persepsi setuju dengan jumlah skor 843. Indikator tersedianya fasilitas lahan parkir di daya tarik wisata jembong mendapat persepsi setuju dengan jumlah skor 866 . Indikator tersedianya fasilitas tempat sampah di sekitar daya tarik wisata Jembong mendapat persepsi setuju dengan jumlah skor 867 . Indikator tersedianya tempat makan dan minum di daya tarik wisata Jembong mendapat persepsi setuju dengan jumlah skor 820 . 
Tabel 15. Persepsi Wisatawan terhadap Accessibility

\begin{tabular}{clcc}
\hline No & \multicolumn{1}{c}{ Indikator Accesibility } & Skor & $\begin{array}{c}\text { Klasifikasi } \\
\text { Sikap }\end{array}$ \\
\hline 1 & $\begin{array}{l}\text { Mudahnya akses menuju Daya Tarik } \\
\text { Wisata Jembong }\end{array}$ & 900 & Setuju \\
\hline \multirow{2}{*}{$\begin{array}{l}\text { Adanya papan petunjuk menuju Daya } \\
\begin{array}{l}\text { Tarik Wisata Jembong untuk } \\
\text { memudahkan wisatawan menuju daya } \\
\text { tarik wisata Jembong }\end{array}\end{array}$} & 945 & Setuju \\
\hline 3 & $\begin{array}{l}\text { Mudahnya jalur trekking atau jalur } \\
\text { menuju Air Terjun Jembong }\end{array}$ & 934 & Setuju \\
\hline 4 & $\begin{array}{l}\text { Adanya tangga menuju Air Terjun untuk } \\
\text { memudahkan wisatawan }\end{array}$ & 989 & Sangat Setuju \\
\hline 5 & $\begin{array}{l}\text { Adanya jalan setapak menuju Air Terjun } \\
\text { untuk memudahkan wisatawan }\end{array}$ & 952 & Sangat Setuju \\
\hline$\quad$ Rata-rata & 944 & Setuju \\
\hline
\end{tabular}

Sumber: Hasil Penelitian, 2017.

Secara umum persepsi wisatawan terhadap accesibility dikatakan setuju dengan rata-rata skor 944. Indikator yang mendapat penilaian sangat setuju adalah adanya tangga menuju air terjun untuk memudahkan wisatawan dengan skor 989 dan adanya jalan setapak menuju air terjun untuk memudahkan wisatawan dengan skor 952. Indikator yang mendapat penilaian setuju dari wisatawan adalah mudahnya akses menuju daya tarik wisata Jembong dengan skor 900, adanya papan petunjuk menuju daya tarik wisata Jembong untuk mempermudah wisatawan menuju daya tarik wisata Jembong, dan mudahnya jalur trekking atau jalur menuju air terjun Jembong.

Tabel 16. Persepsi Wisatawan terhadap Ancilary Service

\begin{tabular}{clcl}
\hline No & \multicolumn{1}{c}{ Indikator Ancilary Service } & Skor & $\begin{array}{c}\text { Klasifikasi } \\
\text { Sikap }\end{array}$ \\
\hline 1 & $\begin{array}{l}\text { Tersedianya Brosur Wisata sebagai Media } \\
\text { Promosi di Daya Tarik Wisata Jembong }\end{array}$ & 808 & Setuju \\
\hline 2 & $\begin{array}{l}\text { Adanya Pusat Informasi Wisatawan di daya } \\
\text { tarik Wisata Jembong }\end{array}$ & 833 & Setuju \\
\hline $\begin{array}{l}\text { Tersedianya email dan instagram sebagai } \\
\text { media promosi dan informasi di daya tarik } \\
\text { wisata Jembong }\end{array}$ & 830 & Setuju \\
\hline 4 & $\begin{array}{l}\text { Adanya peta yang menunjukkan lokasi Daya } \\
\text { tarik Wisata Jembong }\end{array}$ & 865 & Setuju \\
\hline \multicolumn{2}{c}{ Rata-rata } & 834 & Setuju \\
\hline
\end{tabular}

Sumber: Hasil Penelitian, 2017.

Sesuai dengan tabel 15 bahwa rata-rata penilaian wisatawan terhadap indikator ancilary service adalah setuju dengan sor 834 . Empat indikator yang dinyatakan peneliti kepada wisatawan mendapat penilaian setuju yaitu indikator tersedianya brosur wisata sebagai media promosi di daya tarik wisata Jembong dengan skor 808, indikator adanya pusat informasi wisatawan di daya tarik wisata
Jembong dengan skor 833, indikator tersedianya email dan instagram sebagai media promosi dan informasi di daya tarik wisata Jembong dengan skor 830, dan adanya peta yang menunjukkan lokasi daya tarik wisata Jembong dengan skor 865 .

Motivasi Wisatawan yang Berkunjung ke Daya Tarik Wisata Jembong 
Tabel 17. Motivasi Pendorong Wisatawan

\begin{tabular}{clcc}
\hline No & \multicolumn{1}{c}{ Indikator Push Motivation } & Skor & $\begin{array}{c}\text { Klasifikasi } \\
\text { Sikap }\end{array}$ \\
\hline 1 & $\begin{array}{l}\text { Untuk mengunjungi Wisata Air Terjun yang } \\
\text { belum pernah dikunjungi sebelumnya }\end{array}$ & 950 & Setuju \\
\hline 2 & $\begin{array}{l}\text { Untuk mewujudkan mimpi mengunjungi daya } \\
\text { tarik wisata }\end{array}$ & 887 & Setuju \\
\hline 3 & $\begin{array}{l}\text { Untuk mengunjungi wisata air terjun yang } \\
\text { pernah dikunjungi oleh teman }\end{array}$ & 898 & Setuju \\
\hline 4 & $\begin{array}{l}\text { Untuk mendapatkan pengalaman baru di tempat } \\
\text { yang baru }\end{array}$ & 983 & Sangat Setuju \\
\hline 5 & Untuk merelaksasikan diri & 961 & Sangat Setuju \\
\hline 6 & Untuk melepaskan diri dari rutinitas sehari-hari & 916 & Setuju \\
\hline 7 & $\begin{array}{l}\text { Untuk menikmati alam pedesaan dan suasana } \\
\text { air terjun }\end{array}$ & 989 & Sangat Setuju \\
\hline 8 & $\begin{array}{l}\text { Untuk menikmati waktu dengan teman } \\
\text { seperjalanan }\end{array}$ & 976 & Sangat Setuju \\
\hline 9 & $\begin{array}{l}\text { Untuk melakukan trekking di daya tarik wisata } \\
\text { baru }\end{array}$ & 896 & Setuju \\
\hline Rata-rata & 939,5 & Setuju \\
\hline
\end{tabular}

Sumber: Hasil Penelitian, 2017.

Variabel motivasi pendorong terdapat 9 indikator yang dinyatakan oleh peneliti dengan rata-rata skor 939,5 yang mendapat penilaian setuju. indikator yang mendapat penilaian sangat setuju adalah untuk menikmati alam pedesaan dan suasana air terjun yang mendapat skor tertinggi yaitu 989, kemudian di urutan kedua adalah untuk mendapatkan pengalaman baru di tempat yang baru dengan skor 983, untuk menikmati waktu dengan teman seperjalanan dengan skor 976 dan untuk merelaksasikan diri dengan skor 961. Sedangkan indikator yang mendapat penilaian setuju adalahUntuk mengunjungi Wisata Air Terjun yang belum pernah dikunjungi sebelumnyadengan skor 950, Untuk melepaskan diri dari rutinitas seharihari dengan skor 916, Untuk mengunjungi wisata air terjun yang pernah dikunjungi oleh teman dengan skor 898, Untuk melakukan trekking di daya tarik wisata baru dengan skor 896, dan Untuk mewujudkan mimpi mengunjungi daya tarik wisata dengan skor 887 merupakan indikator dengan skor terendah.

Tabel 18. Motivasi Penarik Wisatawan

\begin{tabular}{rlcc}
\hline No & \multicolumn{1}{c}{ Indikator Pull Motivation } & Skor & $\begin{array}{c}\text { Klasifikasi } \\
\text { Sikap }\end{array}$ \\
\hline 1 & Daya tarik Wisata yang aman & 930 & Setuju \\
\hline 2 & Pemandangan alam yang indah & 1001 & Sangat Setuju \\
\hline 3 & Air yang jernih & 984 & Sangat Setuju \\
\hline 4 & Air terjun yang unik & 975 & Sangat Setuju \\
\hline 5 & Kolam alami dibawah air terjun & 983 & Sangat Setuju \\
\hline 6 & Spot foto unik di kolam selfie & 973 & Sangat Setuju \\
\hline 7 & Jalur Trekking yang mudah untuk dilalui & 915 & Setuju \\
\hline 8 & $\begin{array}{l}\text { Pemandangan sawah terasering dan kebun } \\
\text { cengkeh selama trekking }\end{array}$ & 942 & Setuju \\
\hline 9 & Spot foto yang eksotis di pusat trekking & 939 & Setuju \\
\hline \multicolumn{2}{l}{ Rata-rata } & 960.2 & Sangat Setuju \\
\hline
\end{tabular}

Sumber: Hasil Penelitian, 2017. 
Secara umum wisatawan memberikan penilaian sangat setuju dengan rata-rata skor 960,2 terhadap motivasi penarik yang ada di daya atrik wisata Jembong. Dari sembilan indikator, lima indikator mendapat penilaian sangat setuju dan empat indikator mendapat penilaian setuju. Indikator yang mendapat penilaian sangat setuju diantaranya adalah pemandangan alam yang indah yang mendapat skor tertinggi yaitu 1001, di ururtan kedua adalah air yang jernih dengan skor 984, kolam alami dibawah air terjun mendapat skor 983, air terjun yang unik dengan skor 975, dan spot foto unik di kolam selfie dengan skor 973. Sedangkan indikator yang mendapat penilaian setuju adalah Pemandangan sawah terasering dan kebun cengkeh selama trekking dengan skor 942, Spot foto yang eksotis di pusat trekking dengan skor 939, Daya tarik Wisata yang aman dengan skor 930, dan Jalur Trekking yang mudah untuk dilalui dengan skor 915 merupakan indikator dengan skor terendah.

Motivasi wisatawan yang mengunjungi daya tarik wisata Jembong baik itu motivasi pendorong maupun motivasi penarik, indikator yang mendapat penilaian tertinggi adalah yang berkaitan dengan menikmati keindahan alam. Hal ini ditunjang dengan aktivitas yang dominan wisatawan lakukan selama di daya tarik wisata Jembong adalah menikmati keindahan alam dan fotografi. Dilihat dari motivasi wisatawan tersebut, persepsi wisatawan mengenai alam yang mendapat nilai tertinggi yaitu kesegaran udara dan keindahan alam di daya tarik wisata Jembong. Dilihat dari hasil tersebut dapat dikatakan bahwa apa yang wisatawan jadikan alasan berkunjung ke daya tarik wisata Jembong dan yang diharapkan oleh wisatawan sesuai dengan yang didapatkan wisatawan di daya tarik wisata Jembong.

\section{SIMPULAN DAN SARAN Simpulan}

Daya tarik wisata Jembong terletak di Dusun Jembong, Desa Ambengan, Kecamatan Sukasada, Kabupaten Buleleng yang memiliki beberapa aktivitas yang dapat dilakukan oleh wisatawan yang datang berkunjung. Aktivitas tersebut antara lain, menikmati keindahan alam air terjun dan sekelilingnya, berendam dan berenang di kolam alami yang berada di bawah air terjun, fotografi dan trekking. Aktivitas yang paling banyak diminati oleh wisatawan adalah fotografi dan menikmati keindahan alam.

Persepsi wisatawan yang berkunjung terhadap empat komponen utama penunjang suatu destinasi dapat dikategorikan setuju. Pada komponen attraction persepsi wisatawan dengan nilai tertinggi terdapat pada kesegaran udara dan keindahan alam di daya tarik wisata Jembong. Di komponen amenities persepsi wisatawan tertinggi adalah Tersedianya fasilitas gazebo atau bale bengong sebagai tempat istirahat di daya tarik wisata Jembong. Komponen ketiga yaitu komponen accessibility persepsi wisatawan tertinggi adalah adanya tangga menuju air terjun Jembong. Komponen terakhir adalah ancilary service yang mendapat nilai tertinggi dari persepsi wisatawan terletak pada adanya peta yang menujukkan lokasi daya tarik wisata Jembong.

Sedangkan untuk motivasi wisatawan yang berkunjung ke daya tarik wisata Jembong menggunakan motivasi pendorong dan penarik. Motivasi pendorong yang paling tinggi mendapat penilaian dari wisatawan adalah untuk menikmati alam pedesaan dan suasana air terjun. Sedangkan untuk motivasi penarik yang mendapat penilaian tertinggi adalah pemandangan alam yang indah. Hal ini berarti motivasi utama wisatawan yang berkunjung ke daya tarik wisata Jembong berkaitan dengan pemandangan alam yang ada di daya tarik wisata Jembong.

Motivasi pendorong dan motivasi penarik ini sesuai dengan aktivitas yang dominan dilakukan di daya tarik wisata Jembong juga sesuai dengan persepsi wisatawan yang mendapat nilai tertinggi yaitu kesegaran udara dan keindahan alam di daya tarik wisata Jembong. Sehingga hal yang wisatawan harapkan sesuai dengan hal yang wisatawan dapatkan di daya tarik wisata Jembong.

\section{Saran}

Saran yang dapat disampaikan oleh peneliti kepada kelompok sadar wisata Banten Sari selaku pengelola daya tarik wisata Jembong, antara lain:

1. Meningkatkan pelayanan serta fasilitas yang mendukung kenyamanan wisatawan seperti kebersihan toilet dan ketersediaan 
tempat makan dan minum serta membuat cinderamata khas dusun Jembong sebagai pengingat akan daya tarik wisata Jembong

2. Melakukan strategi penyebaran brosur di tempat-tempat wisata lainnya, sehingga langsung sampai di tangan wisatawan itu sendiri.

3. Meningkatkan promosi melalui media sosial dan internet sehingga lebih banyak wisatawan baik itu wisatawan lokal maupun wisatawan international yang mengetahui daya tarik wisata Jembong.

4. Mengelola kembali jalur trekking menjadi lebih menarik dan mempromosikannya kepada wisatawan yang berkunjung ke daya tarik wisata Jembong.

5. Bekerja sama dengan pejabat desa yang bertugas untuk mempermudah jalan meuju daya tarik wisata Jembong. 


\section{Kepustakaan}

Alegre, Joaquín and Magdalena Cladera. 2012. "Tourist Characteristics That Influence Shopping Participation And Expenditures" Jurnal International Journal Of Culture, Tourism And Hospitality Research,vol. 6,no. 3, pp. 223-237.

Bungin, H.M. Burhan. 2013. Metodologi Penelitian Sosial \& Ekonomi. Jakarta: Prenadamedia Group.

Butarbutar, Regina Rosita dan Soemarno. 2013. "Pengaruh Aktivitas Wisatawan terhadap Keanekaragaman Tumbuhan di Sulawesi" Journal of Indonesian Tourism and Development Studies, vol.1,no.2,pp. 87-96.

Hermansyah, Danu dan Bagja Waluya. 2012. "Analisis Faktor-Faktor Pendorong Motivasi Wisatawan Nusantara Terhadap Keputusan Berkunjung Ke Kebun Raya Bogor (Survei Pada Wisatawan Nusantara yang Berkunjung ke Kebun Raya Bogor)"Tourism and Hospitality Essentials (THE) Journal, vol. 11,no.1,pp. 245-268.

Marpaung, Happy. 2002. Pengetahuan Kepariwisataan. Bandung: Penerbit Alfabeta.

Mat Som, Ahmad Puad. 2010. "An Analysis of Push and Pull Travel Motivations of Foreign Tourists to Jordan" International Journal of Business and Management,vol. 5, no. 12, pp. 41-50.

Mehmetoglu, Mehmet and Øystein Normann. 2013. "The Link Between Travel Motives And Activities In Nature-Based Tourism" Tourism Review,vol. 68,no. 2, pp. 3-13.

Murianto. 2014. "Potensi dan Persepsi Masyarakat serta Wisatawan Terhadap Pengembangan Ekowisata di Desa Aik Berik, Lombok Tengah" Jurnal Master Pariwisata,vol. 1,no 1, pp. 43-64.

Nurjaya, I Wayan. 2011. "Daya Tarik Dan Aktivitas Pariwisata Yang Digemari Wisatawan Mancanegara di Kelurahan
Ubud" Jurnal Perhotelan dan Pariwisata,vol. 1,no.2, pp. 1-11.

Nurjaya, I Wayan. 2011. "Persepsi Wisatawan Mancanegara terhadap Fasilitas Umum di Kawasan Pariwisata Ubud" Jurnal Perhotelan dan Pariwisata,vol. 2,no.1, pp. 25-36.

Pitana, I Gde dan I Ketut Surya Diarta. 2009. Pengantar Ilmu Pariwisata. Yogyakarta: Penerbit Andi.

Pitana, I Gde dan Putu G Gayatri. 2005. Sosiologi Pariwisata. Yogyakarta: Penerbit Andi.

Rabotic, Branislav. 2011. “American tourists' perceptions of tourist guides in Belgrade" UTMS Journal of Economics, vol. 2, no. 2, pp. 151-161.

Sugiyono. 2007. Statistik untuk Penelitian. Bandung: Penerbit Alfabeta.

. 2014. Metode Penelitian Kuantitatif, Kualitatif dan R\&D. Bandung: Penerbit Alfabeta. Manajemen. Bandung: Penerbit Alfabeta.

J. 2000. Statistik, Teori dan Aplikasi. Jakarta: Erlangga

Suwena, I Ketut dan I Gst Ngr Widyatmaja. 2010. Pengetahuan Dasar Ilmu Pariwisata. Denpasar: Udayana University Press.

Undang-Undang Republik Indonesia Nomor 10 Tahun 2009 Tentang Kepariwisataan.

Herdiana, Lisa. 2012. "Daya Tarik dan Kawasan Wisata". Tersedia: http://lisaherdiana.blogspot.co.id/2012/0 4/daya-tarik-dan-kawasan-wisata.html (Accessed: 27 Juni 2016).

. 2014. Direktori Obyek dan Daya tarik Wisata 2014. (Online). Tersedia: http://www.disparda.baliprov.go.id/ [23 Agustus 2017. 